\title{
Suction drainage: a new approach to the treatment of empyema
}

\author{
A R C Cummin, N L Wright, A E A Joseph
}

\begin{abstract}
Thirteen patients with empyema thoracis were treated with a new suction drainage technique. The method entails passing a catheter into the empyema cavity under ultrasound guidance and using strong suction to drain loculated pus. Eight patients had no recurrence after a single treatment and one patient had no recurrence after two treatments. The procedure was a useful palliative measure in two patients with malignant disease who subsequently died. In one patient failure of the lung to expand after the procedure showed the need for thoracotomy. In one other patient the empyema recurred and decortication was required.
\end{abstract}

Antibiotics have decreased the incidence of empyema but basic surgical principles still determine the management of established cases. The aim is to drain the pus and obliterate the space. Needle thoracocentesis may not be successful and about a third of patients who have closed tube drainage subsequently require open drainage or thoracotomy. ${ }^{1}$ In a recent series the failure rate for chest tube drainage was as high as $65 \% .^{2}$ Blockage of the tube with thick pus or debris, kinking of the tube, poor positioning of the tube, or loculation of the empyema may cause closed tube drainage to fail. Even if these problems are avoided, drainage may still fail to close the space once an empyema has become chronic.

Recognising these difficulties, we have developed a suction drainage technique that allows thick pus and debris to be aspirated quickly and completely. We believe that this approach has saved thoracotomy in some patients and has determined the need for thoracotomy rapidly in others. Here we present an audit of our results.

Medicine, St George's

Hospital Medical

School, London

A R C Cummin

Regional

Cardiothoracic Unit

N L Wright

Department of

Radiology

A E A Joseph

St George's Hospital, London

Reprint requests to:

Dr Cummin

Accepted 13 December 1990 inserted into the empyema cavity. The trocar was removed and an Argyl or Portex catheter (20-28 FG) was passed into the empyema and connected to strong suction $(-100 \mathrm{~mm} \mathrm{Hg}$ $(-13 \mathrm{kPa}))$. The cannula was directed under ultrasound guidance and the catheter could thus be passed into most parts of the empyema cavity and any septa present broken so that loculated pus could be removed. The drain was then removed and the skin sutured.

Every patient with empyema admitted under the care of a single thoracic surgeon over a period of four years was identified. Of a total of 20 patients, six were considered to need urgent thoracotomy. Two of these patients had a ruptured oesophagus that required repair, one patient required thoracotomy for diagnosis, and one had an underlying bronchial carcinoma, which it was thought might be resectable. The other two patients had a history of recurrent empyema dating back 8-10 years and decortication was considered necessary. Of the remaining 14 patients, closed tube drainage was started in another hospital in one patient and was continued; the rest were treated with suction drainage, which in one case was followed by closed tube drainage. All but one of the patients who received suction drainage had already received needle thoracocentesis, closed tube drainage, or both elsewhere and had been transferred with a view to having a more major surgical procedure.

\section{Results}

The table shows the details of the patients who did not require immediate thoracotomy. In 11 of the 13 patients who received suction drainage there was an initial good result with a rapid clinical improvement and at least partial reexpansion of the lung on the first radiograph after suction. For one patient (No 4) suction drainage was helpful in defining the need for thoracotomy as the radiographs taken after the evacuation of pus showed a persistent large pleural air space and a thick cortex on the lung surface with little re-expansion of the lung. The ultrasound examination of patient 11 showed a large empyema and in addition a collection of pus between the muscle and the subcutaneous tissues, which the strong suction aspiration failed to drain; she subsequently required decortication. Of the 11 patients who improved initially after suction drainage, two subsequently died of an underlying malignancy; in these patients suction drainage had had a useful palliative effect. The other patients remain well. 
Details of the patients who did not require immediate thoracotomy after drainage ${ }^{\star}$

\begin{tabular}{|c|c|c|c|c|c|c|c|}
\hline $\begin{array}{l}\text { Patient } \\
\text { No }\end{array}$ & $\begin{array}{l}\text { Age } \\
(y)\end{array}$ & Sex & $\begin{array}{l}\text { Duration of } \\
\text { empyema } \\
(w k)\end{array}$ & Aetiology & Culture & Outcome & $\begin{array}{l}\text { Days in } \\
\text { hospital after } \\
\text { suction drainage }\end{array}$ \\
\hline 1 & 79 & $\mathbf{M}$ & 8 & Postoperative pneumonia & Mixed growth & No recurrence after 9 months & - \\
\hline 2 & 75 & $\mathbf{M}$ & 8 & Lobar pneumonia & Mixed anaerobes & No recurrence after 11 months & 8 \\
\hline 3 & 14 & $\mathbf{M}$ & 12 & Presumed pneumonia & Streptococcus milleri & No recurrence after 9 months & 7 \\
\hline 4 & 30 & $\mathrm{~F}$ & 3 & Lobar pneumonia & No growth & $\begin{array}{l}\text { Persisting air space and } \\
\text { fluid reaccumulation- } \\
\text { decortication }\end{array}$ & - \\
\hline 5 & 17 & $M$ & 6 & Lobar pneumonia & Streptococcus pneumoniae & $\begin{array}{l}\text { Recurred after } 8 \text { days, } \\
\text { suction drainage repeated; } \\
\text { no recurrence after } 18 \text { months }\end{array}$ & $\begin{array}{l}5 \\
\text { (after repeat) }\end{array}$ \\
\hline 6 & 78 & $\mathbf{F}$ & 10 & Presumed pneumonia & Streptococcus milleri & No recurrence after 20 months & 2 \\
\hline 7 & 58 & $\mathbf{F}$ & 8 & $\begin{array}{l}\text { Presumed pneumonia, } \\
\text { advanced carcinoma of } \\
\text { breast }\end{array}$ & Streptococcus milleri & $\begin{array}{l}\text { No recurrence; died from cerebral } \\
\text { metastases after } 2 \text { months }\end{array}$ & $\begin{array}{l}\text { (transferred } \\
\text { to hospice) }\end{array}$ \\
\hline 8 & 30 & $M$ & 12 & Lobar pneumonia & No growth & No recurrence after 36 months & 1 \\
\hline 9 & 15 & $\mathbf{M}$ & 8 & Lobar pneumonia & No growth & No recurrence after 43 months & 1 \\
\hline 10 & 64 & $\mathbf{F}$ & 5 & Possible pneumonia & No growth & No recurrence after 41 months & 4 \\
\hline 11 & 54 & $\mathbf{F}$ & 9 & Presumed pneumonia & Streptococcus salivanus & Recurrence-decortication & - \\
\hline 12 & 77 & $\mathbf{M}$ & 10 & Postoperative pneumonia & No growth & No recurrence after 24 months & 2 \\
\hline 13 & 57 & $\mathbf{F}$ & 5 & Lobar pneumonia & No growth & No recurrence after 21 months & 2 \\
\hline 14 & 48 & $\mathbf{M}$ & 3 & Bronchial carcinoma & Streptococcus milleri & $\begin{array}{l}\text { Pneumonectomy } 3 \text { weeks later; } \\
\text { died }\end{array}$ & 2 \\
\hline
\end{tabular}

^Suction drainage except in patient 1 , who had closed tube drainage; patient 10 had closed tube drainage after suction drainage.

\section{Discussion}

The suction drainage technique is quick, safe, and relatively painless and can clear large volumes of pus quickly with rapid clinical improvement. We believe that it has saved a thoracotomy in some patients and in others it has immediately shown that a thoracotomy was necessary. The method avoids the need for an indwelling tube drain and underwater seal with the consequent discomfort, prolonged hospital stay, and relative immobility as well as the problems of drain blockage and malposition. Suction drainage does not require special facilities or the skills of a thoracic surgeon and its use in a district general hospital might obviate the need for transfer to a specialist unit.

Our experience shows that suction drainage is often successful in a difficult group of patients referred with a view to thoracotomy after repeated aspiration or closed tube drainage or both have failed.

1 Varkey B, Rose HD, Kutty CPK, Politis J. Empyema thoracis during a ten-year period. Arch Intern Med 1981;141:1771-6.

2 Lemmer JH, Botham MJ, Orringer MB. Modern management of adult thoracic empyema. $J$ Thorac Cardiovasc Surg 1985;90:849-55. 